\title{
Differences in selected medical care parameters in rheumatic disease ward patients of different ages of life
}

\author{
Piotr Pobrotyn ${ }^{1}$, Robert Susło ${ }^{2}$, Izabela Witczak ${ }^{3}$, Piotr Milczanowski ${ }^{4}$, Jarosław Drobnik ${ }^{5}$ \\ ${ }^{1}$ University Clinical Hospital, General Management, Wroclaw, Poland \\ 2Department of Public Health, University Clinical Hospital, Wroclaw, Poland \\ ${ }^{3}$ Department of Economics and Quality in Health Care, Wroclaw Medical University, Wroclaw, Poland \\ ${ }^{4}$ Voivodship Disability Evaluation Board, LoverSilesia Voivodship Office, Wroclaw, Poland \\ ${ }^{5}$ Department of Gerontology, Wroclaw Medical University, Wroclaw, Poland
}

\begin{abstract}
Introduction: Rheumatic diseases are becoming more and more common in Poland with the ageing of the population. Nearly $18 \%$ of the total hospital admissions in Poland result from rheumatic diseases, which was equivalent to 350 thousand cases in the year 2008. These diseases tend to last for many decades, decreasing both the quality of life and income of the patients as well as increasing the medical institutions' workload and society's financial burden.

The aim of the study was to determine whether the medical care parameters in a rheumatic disease hospital ward show any significant differences among different patient age groups - especially such that would support taking them into account as a basis for adjusting the financial coverage level of medical services.

Material and methods: Data on hospitalizations at the Rheumatic Diseases Ward of Wroclaw University Hospital in Wroclaw in the years 2009-2015 were analyzed, taking into account the age groups, number of hospital admissions, their duration and causes. Relevant statistical data analysis was performed.

Discussion: The study revealed that the number of old patients hospitalized at the rheumatic diseases ward increased over the last 6 years and that such statistically significant differences do exist: on average the old patients not only tend to stay much longer at the hospital, but also suffer from a different and more diverse spectrum of diseases in comparison to their younger counterparts. Conclusions: The detected differences in medical care parameters support the need for more individualized medical care and increased cost of the hospital stay in the case of older patients. Consequently, those factors justify the necessity to increase the value of medical services in the case of old patients, possibly also taking into account the variation between age subgroups.
\end{abstract}

Key words: rheumatic diseases, pharmacoeconomics, public health.

\section{Introduction}

A significant proportion of the Polish population suffers from rheumatic diseases, with a morbidity rate of 4-5\% [1]. Rheumatoid arthritis alone is treated in 150000 Polish patients yearly, with the total estimated population of 400000 people suffering in Poland from inflam- matory joint diseases, including rheumatoid arthritis [2]. Moreover, according to the data on hospital admissions in Poland that were due to diseases of the musculoskeletal system and connective tissue (M00-M99 ICD-10), their number in total increased from 267083 in 2004 to 405801 in 2013, and 396977 in 2014. At the same time,

\footnotetext{
Address for correspondence:

Izabela Witczak, Department of Economics and Quality in Health Care, Wroclaw Medical University, Bartla 5, 51-618 Wrocław, Poland,

e-mail: izaeuro@wp.pl

Submitted: 25.04.2016; Accepted: 28.04.2016
} 
the number of patients in the age group of 65 years and more increased in the respective years from 199385 to 292621 and 280 222. Consecutively, among the patients admitted to Polish hospitals because of diseases of the musculoskeletal system and connective tissue, the proportion of patients in the age group of 65 years and more increased from $25.35 \%$ in 2004 to $29.41 \%$ in 2014 [3].

Rheumatic diseases decrease life quality in many aspects: medical, psychological [4] and social - and only to a limited degree can it be modified by therapy [5]. Because of the specific clinical course of rheumatic diseases, it is very difficult to set realistic long-term therapeutic goals [6]. More and more often the cost resulting from rheumatic diseases becomes the object of interest for epidemiologists and medical economists [7]. Long-term analysis is biased because of classification criteria changes that were introduced for many rheumatic diseases; it becomes even more difficult as some of those diseases are not diagnostically defined clearly enough [1].

As with the progress of rheumatic diseases the degree of patients' functional disability increases [1], such diseases are associated with significant costs that can be divided into direct, indirect and immeasurable costs [2]. Rheumatic diseases result in: progressive loss of productivity [8], increasing difficulties in performing everyday activities [9], often ending finally in total dependency on others [10]. The above-mentioned dynamics results in limited ability of patients with rheumatic diseases to gain income and, at the same time, in doubling of health-related expenses [11]. In old age, apart from rheumatoid arthritis, typically mentioned in this context, the most common rheumatic diseases sensu lato include: systemic involvement of connective tissue and gout [12]. The prevalence of rheumatic diseases tends to increase with age and - combined with the aging of the population - it means increasing the burden on the medical services; it is significant even now as the rheumatic diseases are ranked in the $8^{\text {th }}$ place among the most burdensome diseases. In 2009 the Social Insurance Fund (Fundusz Ubezpieczeń Społecznych) in Poland paid to rheumatic disease patients around PLN 3500000000 because of absence from work alone - which represents $12.6 \%$ of the total amount of work absence-related expenses [1]. In 2014 the respective payments increased to around PLN 4250000 and the percentage of expenses increased to $13.1 \%$ [13]. An average insured person in Poland had to pay PLN 155 because of this - which makes the rheumatic diseases $3^{\text {rd }}$ among the most expensive health conditions, just behind circulatory system diseases and psychiatric diseases (PLN 193 and PLN 191, respectively) [1]. In 2014 the ranking stayed unchanged, but the amounts of money increased significantly to: PLN 181, PLN 240 and PLN 194, respectively [13]. Nearly
$18 \%$ of hospitalizations in Poland result from rheumatic diseases - in 2008 there were about 350000 hospital admissions of this kind. The hospitalizations resulted mainly from: systemic connective tissue diseases (3.8\%) other than rheumatoid arthritis (RA), systemic lupus erythematosus (SLE) and systemic scleroderma (SSc) and RA alone (1.71\%), SLE (1.18\%), SSc (0.45\%) [1]. In the case of rheumatic disease patients the average hospitalization duration in Poland decreased significantly over the last several years - however, the typical analysis based on number of hospitalizations and duration does not adequately mirror the large scale of burden on the hospitals; the statistics reflect neither multiple admissions of the same patients over a short time nor their cumulative duration in the case of individual patients [14]. In the case of rheumatic diseases significant numbers of diagnoses are established at quite a young age, and over many subsequent decades of life such patients require complex and individualized medical care [15]. It is the established truth that the ageing processes involve human tissues at different paces [16] and even currently rheumatic diseases related expenses consume a significant part of resources reserved for old people care [17]. The burden associated with crippling rheumatic diseases is even more important in Poland, where for many decades there has been a deficit of places observed in both medical and care institutions - which is especially drastic in the case of places for old and dependant patients [18].

The importance of rheumatic diseases development and the resulting challenges for Polish society call for shaping of health and social policies based on in-depth analysis of the needs of patients with rheumatic diseases - aiming at limiting both economic and social costs [19]. Unfortunately, rheumatic disease patients are admitted not only to the respective specialized hospital wards but also to wards of other profiles, among them mainly rehabilitation, surgery, neurology, pediatric and internal disease wards [14]. This means that medical care parameters retrieved from analysis of a rheumatic disease ward - however valuable - do not mirror fully the characteristics and dynamics of processes in the field of the whole rheumatic disease patient group.

\section{Aim of the study}

The aim of the study was to evaluate the differences in selected parameters of care over rheumatic disease ward patients and to compare them between different age groups - so that any significant differences of such parameters can be interpreted in terms of differences in the need for financial coverage of medical services, that exist between old age patients and patients of other age groups. 


\section{Material and methods}

Aiming at finding differences between parameters describing the care in the case of old patients and others, an analysis of hospitalization data in the years 20092015 in the Rheumatic Diseases Ward of the University Clinical Hospital, Wroclaw, Poland was performed. The differences in hospital admission numbers in different years, numbers of patients belonging to different age groups, duration of hospitalizations as well as causes of hospital admissions were analyzed first using the age groups of 64 years and less, and 65 years and more; and then subdividing the old patient group into subgroups: 65-74 years, $75-84$ years, and 85 years and more. Statistics were calculated using the $\chi^{2}$ of highest credibility. In the case of hospitalization duration statistical significance ( $p=0.000$ ) of differences was calculated, because of pronounced data distribution asymmetry, using the non-parametric Kruskal-Wallis ANOVA test and multiple post hoc comparisons test.

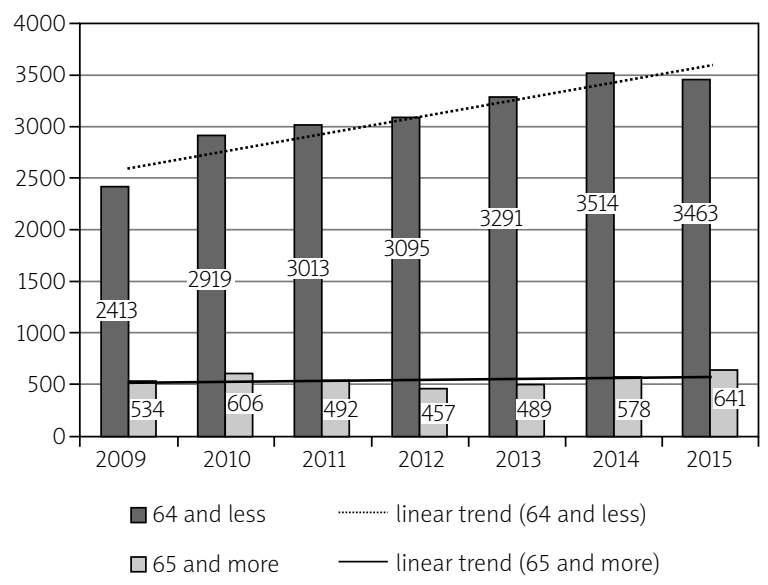

Fig. 1. Hospital admissions to Rheumatic Diseases Ward in the years 2009-2015 divided into main age groups and years.

\section{Results}

Figures 1 and 2 show the changes in the number of patients admitted to the Rheumatic Diseases Ward divided into age groups and subgroups. Table I shows patients' age subgroups - 65-74 years, 75-84 years, and 85 years and more - representations within the age group 65 years and more.

Table II lists hospitalization times of Rheumatic Diseases Ward patients generally and divided into age groups.

Tables III and IV show data on the most common hospital admission causes in the Rheumatic Diseases Ward, divided into age groups and subgroups.

\section{Discussion}

Hospitalization analyses in the Lower Silesia region - including location [20], causes and patient age groups - have been carried out systematically by some authors

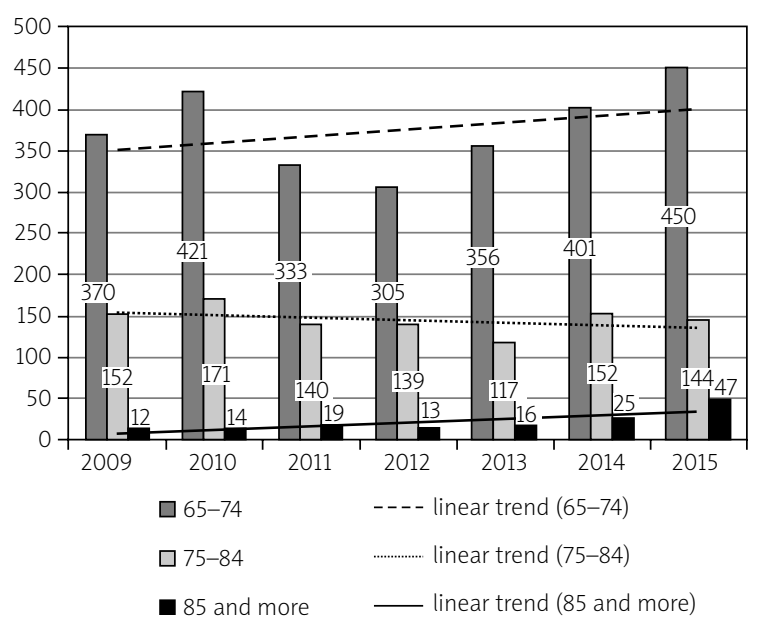

Fig. 2. Numbers of hospital admissions to Rheumatic Diseases Ward in the years 2009-2015, divided into age subgroups and years.

Table I. Percentage of age group 65 years and more hospital admissions to Rheumatic Diseases Ward in the years 2009-2015, divided into age subgroups

\begin{tabular}{|c|c|c|c|c|}
\hline \multirow[t]{2}{*}{ Year } & \multicolumn{3}{|c|}{ Age group (\%) } & \\
\hline & $65-74$ years & $75-84$ years & 85 years and more & \\
\hline 2009 & 69.3 & 28.5 & 2.2 & 100.0 \\
\hline 2010 & 69.5 & 28.2 & 2.3 & 100.0 \\
\hline 2011 & 67.7 & 28.5 & 3.9 & 100.0 \\
\hline 2012 & 66.7 & 30.4 & 2.8 & 100.0 \\
\hline 2013 & 72.8 & 23.9 & 3.3 & 100.0 \\
\hline 2014 & 69.4 & 26.3 & 4.3 & 100.0 \\
\hline 2015 & 70.2 & 22.5 & 7.3 & 100.0 \\
\hline
\end{tabular}

Source: authors' study 
Table II. Hospitalization duration in Rheumatic Diseases Ward calculated as cumulative values for years 2009-2015

\begin{tabular}{|lc|}
\hline & Person-days \\
\hline Total - no age groups & 40255 \\
\hline Age group 64 years and less & 36528 \\
\hline Age group 65 years and more & 61567 \\
\hline Source: authors' study &
\end{tabular}

for many years now [21]. Data acquired from different sources are inconsistent to a level that significantly impairs any attempt to analyze not only the local population's illness burden level but also the dynamics, or even directions, of changes [22]. Data gathered by a large regional hospital that has for many years been continuously active in the same sector of the medical services market, even though substantial changes to the other structures of the hospital were made - as the University Clinical Hospital in Wroclaw is - provide precious but obviously incomplete information on local population epidemiological phenomena and directions of their changes.

The number of patients belonging to the age group of 65 years and more, admitted to the Rheumatic Diseases Ward, increased lightly, but their proportion out of the total number of the Ward's patients dropped insignificantly - which resulted from the systematic and constant increase of admissions in younger patient groups.

The analysis of the hospital admissions of patients belonging to the age group of 65 years and more, when divided into age subgroups, revealed that the number of admissions to the Rheumatic Diseases Ward systematically increased over the years in the age subgroups of 85 years and more and 65-74 years. Because of this, within the analyzed time period there was observed a 5\% shift from the age subgroup 75-84 years to the age subgroup 85 years and more; while the proportion of the age subgroup 65-74 years remained practically unchanged.

With the only exception of the year 2009, the hospitalization time in the Rheumatic Diseases Ward expressed in person-days showed statistically significant differences between the age groups of 64 years and less and 65 years and more. It means proven existence of significant differences of hospitalization costs among patients belonging to different age groups - even without taking into account the differences in their hospital admission causes.

Also the analysis performed on the complete data set - from the whole time period - divided into the age subgroups -64 years and less, 65-74 years, 75-84 years and 85 years and more - confirmed the statistically sig-
Table III. Percentage of hospital admissions to Rheumatic Diseases Ward in the years 2009-2015, divided into age groups and main causes according to ICD-10

\begin{tabular}{|ccc|}
\hline \multirow{2}{*}{$\begin{array}{c}\text { Disease } \\
\text { ICD-10) }\end{array}$} & \multicolumn{2}{c|}{ Age group (\%) } \\
\cline { 2 - 3 } & 64 years and less & 65 years and more \\
\hline M05 & 33.90 & 43.01 \\
\hline M45 & 15.06 & 3.77 \\
\hline M35 & 10.70 & 13.27 \\
\hline L40 & 8.18 & 1.79 \\
\hline M32 & 4.99 & 1.98 \\
\hline M06 & 4.23 & 3.71 \\
\hline M34 & 3.88 & 3.74 \\
\hline M15 & 2.85 & 8.06 \\
\hline M13 & 3.48 & 3.27 \\
\hline M31 & 3.01 & 3.40 \\
\hline M33 & 1.71 & 1.55 \\
\hline M02 & 1.61 & 0.42 \\
\hline M48 & 0.76 & 0.58 \\
\hline M46 & 0.81 & 0.24 \\
\hline M30 & 0.73 & 0.32 \\
\hline M10 & 0.44 & 0.87 \\
\hline M08 & 0.55 & 0.00 \\
\hline M80 & 0.13 & 1.84 \\
\hline M81 & 0.22 & 1.29 \\
\hline other & 2.75 & 6.90 \\
\hline & 100.00 & 100.00 \\
\hline
\end{tabular}

nificant differences in the hospitalization durations in the Rheumatic Diseases Ward between all these subgroups of patients. However, the analysis performed on the data divided into particular years revealed that those differences between age subgroups were not always present - for example in 2009 they were absent, while they were significant in all the later years. Those results support the demand to introduce different hospitalization cost tariffs according to patient age groups - which may not have been needed even several years ago. The smallest differences in hospitalization duration were between the age subgroups 75-84 years and 85 years and more - which could preliminarily suggest putting those subgroups into a common hospitalization cost tariff; however, such an approach is not proven adequate according to the further results of the study.

The analysis performed on the complete data set revealed much more diverse hospitalization causes in the Rheumatic Diseases Ward in the age group of 65 years and more than in the age group of 64 years and less: $90 \%$ of hospital admissions in the latter group were caused 
Table IV. Percentage of hospital admissions to Rheumatic Diseases Ward in the years 2009-2015, divided into age subgroups and main causes according to ICD-10

\begin{tabular}{|c|c|c|c|c|}
\hline \multirow{2}{*}{$\begin{array}{l}\text { Disease } \\
\text { (ICD-10) }\end{array}$} & \multicolumn{4}{|c|}{ Age group (\%) } \\
\hline & 64 years and less & $65-74$ years & $75-84$ years & 85 years and more \\
\hline M05 & 33.90 & 45.86 & 40.39 & 9.59 \\
\hline M45 & 15.06 & 5.24 & 0.49 & 0.00 \\
\hline M35 & 10.70 & 12.52 & 15.57 & 10.96 \\
\hline$\llcorner 40$ & 8.18 & 2.24 & 0.89 & 0.00 \\
\hline M32 & 4.99 & 2.24 & 1.58 & 0.00 \\
\hline M06 & 4.23 & 3.53 & 4.73 & 0.00 \\
\hline M34 & 3.88 & 4.17 & 3.15 & 0.00 \\
\hline M13 & 3.48 & 3.53 & 2.86 & 1.37 \\
\hline M31 & 3.01 & 3.49 & 3.55 & 0.68 \\
\hline M15 & 2.85 & 7.06 & 9.56 & 15.75 \\
\hline M33 & 1.71 & 1.75 & 1.18 & 0.68 \\
\hline M02 & 1.61 & 0.53 & 0.10 & 0.68 \\
\hline M46 & 0.81 & 0.30 & 0.10 & 0.00 \\
\hline M48 & 0.76 & 0.53 & 0.49 & 2.05 \\
\hline M30 & 0.73 & 0.46 & 0.00 & 0.00 \\
\hline M08 & 0.55 & 0.00 & 0.00 & 0.00 \\
\hline other & 3.53 & 6.56 & 15.37 & \\
\hline M80* & & & & 14.38 \\
\hline$J 18^{*}$ & & & & 6.16 \\
\hline $163^{*}$ & & & & 3.42 \\
\hline $164^{\star}$ & & & & 2.74 \\
\hline$M 47^{\star}$ & & & & 2.05 \\
\hline $150^{*}$ & & & & 2.05 \\
\hline $148^{\star}$ & & & & 2.05 \\
\hline $\mathrm{G} 45^{\star}$ & & & & 1.37 \\
\hline $169^{*}$ & & & & 1.37 \\
\hline $167^{\star}$ & & & & 1.37 \\
\hline other & & & & 21.23 \\
\hline & 100.00 & 100.00 & 100.00 & 100.00 \\
\hline
\end{tabular}

*The detailed data are shown only for the age group 85 years and more as in case of other age groups the *marked diseases did not belong to main hospital admissions causes

by only 10 main disease groups, and in the former group by 13 disease groups. Nineteen main disease groups did not cover only $2.75 \%$ of cases in the former group, compared to $6.90 \%$ of cases in the latter group. In both age groups $80 \%$ of hospital admissions were caused by 7 main disease groups - but the rate of occurrence of particular diseases was different in each age group: instead of psoriasis and systemic lupus erythematosus in the age group 64 years and less (L40 and M32 ICD-10, respectively) there were systemic connective tissue diseases, mainly Sjögren's syndrome, polymyalgia rheumatica, mixed con- nective tissue disease described by the ICD-10 code M35 and systemic sclerosis (M34 ICD-10).

Taking into account the common coexistence of many coexisting diseases in old age patients, the data concerning the main causes of hospital admissions may not depict fully the health problems of those patients. However, as the result of the study, it was possible to list all main diagnoses established in Rheumatology Ward patients in the years 2009-2015, which were the cause of $90 \%$ of the total number of hospital admissions. Their analysis in the age subgroups - 64 years and less, 65-74 
years, 75-84 years and 85 years and more - revealed significant differences in the most common admission causes among those subgroups. Seropositive rheumatoid arthritis (M05 ICD-10) was the most common cause of hospital admission in all subgroups except the subgroup 85 years and more. The age subgroups 65-74 years and $75-84$ years also shared the $2^{\text {nd }}$ and $3^{\text {rd }}$ most common hospitalization causes, which were, respectively: systemic involvement of connective tissue diseases and osteoarthritis (M35 and M15 ICD-10, respectively), while other causative diseases were different among different age groups. It is striking that the hospital admission causes were totally different in the age group of 85 years and more compared to other age subgroups - in this age subgroup the most common were, in descending order: osteoarthritis, osteoporosis with pathological fracture, systemic involvement of connective tissue diseases, seropositive rheumatoid arthritis and pneumonia (M15, M80, M35, M05 and J18 ICD-10, respectively); in the case of the age group 85 years and more 26 main disease groups are responsible for only $80 \%$ of hospitalizations, while in the general population of patients the same percentage of cases is covered by merely 7 disease groups. Conclusively, although the age subgroup 85 years and more is not numerous, it constitutes a significant diagnostic and therapeutic challenge as the diseases are highly differentiated and non-standard - which supports the demand to put it into a separate hospitalization cost tariff group. It is worth mentioning that putting individuals into different age groups for the purpose of payment adjustments, so the payments associated with older individuals are higher than those related to younger individuals (called age banding), is not uncommon in insurance practices, including medical insurance in other countries [23].

\section{Conclusions}

The data analysis on hospitalizations in the Rheumatic Diseases Ward of the University Clinical Hospital in Wroclaw, in the years 2009-2015, revealed:

In the analyzed time period there was a significant increase in the number of admissions of patients belonging to older age groups to the Rheumatic Diseases Ward. It was consistent with the general 10-year long trend in Poland of a gradually increasing number of hospital admissions because of diseases of the musculoskeletal system including connective tissue diseases.

There are significant differences in medical care parameters provided in the Rheumatic Diseases Ward to patients belonging to older age groups compared to the rest of the patients, which is especially true in the case of the oldest patients; those differences rely particularly on longer average hospitalization duration and a more differentiated set of their causes.

The proven differences in medical care parameters necessitate more individualized and intensive hospital care in the Rheumatic Diseases Ward in the case of patients belonging to older age groups; the different patient age groups - 65-74 years, 75-84 years and 85 years and more - have separate and specific special needs that have to be met by adjusted hospitalization duration, diagnostics, therapy and general care.

To make payments for medical services provided by the Rheumatic Diseases Ward realistic, it is necessary to create other assumptions for the cost of hospitalization in the case of patients belonging to older age groups, as the analysis showed that there is enough evidence to state that those costs are on average much higher in comparison to patients in other age groups.

The authors declare no conflict of interest.

\section{References}

1. Owczarek AJ, Michalik R, Kotyla P, Kucharz EJ. The effects of clinical, epidemiological and economic aspects of changes in classification criteria of selected rheumatic diseases. Reumatologia 2014; 52: 136-141.

2. Raciborski F, Kłak A, Kwiatkowska B. Indirect costs of rheumatoid arthritis. Reumatologia 2015; 53: 268-275.

3. Państwowy Zakład Higieny, Zakład - Centrum Monitorowania i Analiz Stanu Zdrowia Ludności, Badanie Chorobowości Szpitalnej Ogólnej. http://www.statystyka.medstat.waw.pl/ wyniki/wyniki.htm [Access: 9.05.2016]

4. Kulikowski K. Quality of life in the context of psychology and medicine. Reumatologia 2014; 52: 200-206.

5. Wysocka-Skurska I, Sierakowska M, Sierakowski S. Evaluation of the quality of life of patients with rheumatoid arthritis depending on the used therapy. Reumatologia 2012; 50: 16-23.

6. Jankowska-Polańska B, Polański J. Methods of evaluation of the quality of life in rheumatic diseases. Reumatologia 2014; 52: 69-76.

7. Śliwczyński A, Brzozowska M, Illitchev P, et al. Changes in the morbidity and costs of systemic lupus erythematosus in Poland in the years 2008-2012. Reumatologia 2015; 53: 79-86.

8. Raciborski F, Władysiuk M, Bebrysz M, Samoliński B. Productivity loss as a result of rheumatic diseases - absenteeism and presenteeism. Reumatologia 2013; 51: 355-362.

9. Grygielska J. Ocena wybranych dziedzin życia w chorobach reumatycznych - analiza porównawcza badań ankietowych. Reumatologia 2008; 46: 230-234.

10. Bączyk G. The review of investigations of quality of life of patients with rheumatoid arthritis. Reumatologia 2008; 46: 372-379.

11. Grygielska J. The impact of rheumatoid arthritis on the economic situation of Polish households. Reumatologia 2013; 51: 348-354. 
12. Smoleńska Z, Zdrojewski Z. Odmienności w przebiegu chorób reumatycznych $u$ osób w podeszłym wieku. Gerontologia Polska 2010; 18: 169-175.

13. Zakład Ubezpieczeń Społecznych, Departament Statystyki i Prognoz Aktuarialnych Wydatki na świadczenia z ubezpieczeń społecznych związane z niezdolnością do pracy w 2014 r. http://www.zus.pl/files/Wydatki\%20na\%20\%C5\%9Bwiadczenia\%20z\%20ubezpiecze\%C5\%84\%20spo\%C5\%82ecznych\%20 zwi\%C4\%85zane\%20z\%20niezdolno\%C5\%9Bci\%C4\%85\%20 do\%20pracy\%20w\%202014\%20r.pdf pp. 23-28 [Access: 9.05. 2016].

14. Mańczak M, Moskalewicz B. Hospital admissions caused by diseases of the musculoskeletal system in the Silesia Province in 1999-2003. Reumatologia 2008; 46: 10-15.

15. Sudot K, Moskalewicz B. Long-term care in the chronic rheumatic diseases - transition of care between the adolescence and adult care. Reumatologia 2008; 46: 290-294.

16. Di Giulio C, Antosiewicz J, Walski M, et al. Physiological Carotid Body Denervation During Aging. Adv Exp Med Biol 2009; 648: Arterial Chemoreceptors: 257-263.

17. Rosental T, Naughton B, Williams M. Geriatria. Wydawnictwo Czelej, Lublin 2009; 566-567.

18. Raciborski F, Samoliński B. Supply and demand for long-term care services from the perspective of leaders of health care institutions. Reumatologia 2015; 53: 252-259.

19. Gałązka-Sobotka M, Gryglewicz J. Stan zasobów ochrony zdrowia w zakresie reumatologii w Polsce i kierunki ich rozwoju. In: System ochrony zdrowia. Nojszewska E (ed.). Wolters Kluwer Sp. z o.o., Warszawa 2011; 278-305.

20. Drobnik J, Kollbek P, Pobrotyn P. Leczeni w latach 2002 i 2003 w szpitalach ogólnych w województwie dolnośląskim mających kontrakty z Kasą Chorych oraz leczeni w tych szpitalach w roku 1999. In: Analiza wybranych parametrów zdrowotnych mieszkańców Dolnego Śląska w latach 1999-2003. Drobnik J, Kollbek P (eds.). Partner System, Wrocław 2005; 75-77.

21. Drobnik J, Kollbek P, Pobrotyn P. Hospitalizacja niektórych jednostek chorobowych według wybranych grup wiekowych i płci. In: Analiza wybranych parametrów zdrowotnych mieszkańców Dolnego Śląska w latach 1999-2003. Drobnik J, Kollbek P (eds.). Partner System, Wrocław 2005; 97-140.

22. Drobnik J. Ocena wybranych parametrów świadczeń zdrowotnych i systemu sprawozdawczości w ochronie zdrowia w zakresie analizy trendów epidemiologicznych i potrzeb zdrowotnych oraz ich wpływ na wybrane elementy polityki zdrowotnej na podstawie danych z województwa dolnośląskiego. AM, Wrocław 2011; 237-240.

23. Kongstvedt PR. Essentials of Managed Health Care. 6th ed. Jones \& Bartlett Learning, Burlington 2012; 637. 